\title{
Analysis of Changes of the Content and Forms of Organization of the Educational Process in the Conditions of the Introduction of Emergent Technologies
}

\author{
Marina V. Bolsunovskaya ${ }^{1}$, Violetta N. Volkova ${ }^{2}$, Aleksandra V. Loginova ${ }^{3}$, Svetlana V. Shirokova ${ }^{4}$ \\ Peter the Great St. Petersburg Polytechnic University \\ St. Petersburg, Russian Federation \\ 1'marina.bolsunovskaia@ @pbpu.com, ${ }^{2}$ violetta_volkova@list.ru, ${ }^{3}$ alexandra-lo@yandex.ru, ${ }^{4}$ swchirokov@ mail.ru
}

\begin{abstract}
The influence of modern innovative technologies on the content and forms of the educational process is considered. The necessity of interdisciplinary knowledge is substantiated, which is important not only for training specialists in areas related to the development, selection and implementation of new technologies, but also for all specialties, since it helps to navigate the predicted new complex, mobile world of emergent technologies.
\end{abstract}

Keywords - interdisciplinary knowledge; advanced industrial technologies; learning content; educational process; forms of realization of the educational process; emergent technologies condition

\section{INTRODUCTION}

The development of industry in the condition of the introduction of new innovative advanced production and digital technologies, requires prompt personnel training of the necessary qualifications.

The active development of innovative advanced production and information (digital) technologies has a significant impact not only on industrial production, transport, the economy as a whole, but also on all spheres of human life. These technologies cover almost all spheres of science and production - from technical and technological (big data, cloud technologies, etc.) to information processing and transformation technologies (artificial intelligence models, cognitive modeling), creation of analogues of organs of living organisms (3D printing, robotic systems, artificial organs and other results of biotechnology and genetic engineering), etc.

All mentioned types of innovations are united by the integrated use of technology. Therefore, at a certain stage of development, the direction of NBIC technology (nano-, bio-, info-, cognitive technologies) took shape, and the concept of NBICconvergence arose. At the same time, in mathematics, the term "convergence" means only integration (from Lat. Convergo bring together). And although at present there are attempts to interpret this term in an expanded manner, other terms appear [1]. In foreign works, the term "emerging technologies" is often used (from emerge - appear) [13] which means the emergence of new properties as a result of the combination of technologies. The term emerging technologies implies that new results are expected from their use, changes in the level of technological and social development of production, in society, and in the technological progress.

Various concepts of streamlining emergent technologies are emerging. Recently, the social sphere has also been added to the mentioned NBIC technologies, and the term NBICS technologies appeared. The concept of cyberphysical systems (Cyber-Physical System - CPS) arose, based on the integration of computational resources and physical processes (in their expanded understanding, including biological, chemical and other processes) in order to achieve the emergence of fundamentally new opportunities for creating CPSs. To streamline the history of technology development, concepts of technological way of life, industrial revolutions arose.

It should be borne in mind that innovative technologies can have both positive and negative effects on all areas of socioeconomic systems. Therefore, it is necessary to carry out their analysis and make decisions on the appropriateness of their choice for a particular enterprise (organization), taking into account the usefulness and consequences of their outreach, which is important to consider when determining the content of education almost in all specialties.

\section{ANALYSIS OF THE INFLUENCE OF EMERGENT TECHNOLOGIES ON THE CONTENT OF EDUCATION}

New technologies have no analogues, and it is almost impossible to find experts who could evaluate them on the basis of traditional methods of expert evaluations. We need new methods for making decisions on their choice for specific enterprises and organizations. Therefore, a number of new disciplines are needed in which the types and characteristics of technologies, the methods of artificial intelligence, predicative (predictive) analytics, statistics, methods of mathematical linguistics, studying the problems of computer analysis of big data, the synthesis of natural languages, and others are studied.

It is necessary to study hardware (servers, data storage systems, client systems, network equipment); operating systems and system software (virtualization, automation, basic resources management tools); binding software, etc. 
But along with this important information about new "fantastic" technologies, methods and means of working with them, it is important to understand a number of problems arising from their use, which significantly change not only production processes, but also the person's living conditions in the emerging new environment.

The concept of one of the ideologists of the third industrial revolution P. Marsh [2] is based on the fact that after the departure of production from leading countries, both fundamental scientists and knowledge go into the third world. At present, it is necessary to return production to developed countries, not mass production, but combination of expensive and cheap production technologies within the framework of hybrid strategies, to develop new "industry niches", production in which requires complex technologies. K. Anderson [3] predicts that in the near future everyone will be able to create a $3 \mathrm{D}$ model of the necessary thing using a design program (or download a finished program) and "print" it on a home 3D printer. Thus, the development of individual and hybrid production is predicted, the principles of organization of which differ significantly from mass and even serial production. Therefore it is necessary to change the content of education both in the specialties that ensure production processes, and in the field of organizational management.

The ideologist of the fourth industrial revolution, K. Schwab predicts: "At the beginning, the listed innovations will develop separately, but "the critical moment will soon come when they begin to develop, layering and reinforcing each other, representing an interweaving of technologies from the world of physics, biology and digital realities" [4, p. 9]. Thus, in the near future, a person will have to live in a rapidly changing world. Moreover, according to K. Schwab, in its scope, volume and complexity, "The Fourth Industrial Revolution has no analogues in the previous experience of mankind. New technologies unite the physical, informational and biological worlds, are capable of creating, on the one hand, enormous opportunities, and on the other - a potential threat" [4].

In order to navigate in this complex, constantly changing world, it is necessary to understand the laws of its functioning and development. Therefore, familiarization with interdisciplinary knowledge, and in particular with the theory of systems, is useful for almost all specialties. The open system concept can help.

It is known that the term "open systems" was proposed by the Austrian biologist L. von Bertalanffy as the basic concept of the organismical approach he was develop to the study of biological objects and processes [5]. Recently, this term has been proposed to be used in computer science as well - the concept of an open information system (OIC) has arisen.

In open systems, constantly exchanging mass (matter), energy and information with the environment, unlike closed systems (isolated from the environment), regularities appear that contradict the second principle of thermodynamics. In accordance with this beginning, the general course of physical events in closed systems proceeds in the direction of increasing entropy. At the same time, in open systems according to L. von Bertalanffy, "... the introduction of negentropy is quite possible," that is, a decrease in entropy; and "... such systems can maintain their high level and even develop towards an increase in the order of complexity" [5, p. 42].

L. von Bertalanffy actually discovered a new regularity in open systems - "the ability to withstand entropic (systemdestroying) tendencies and exhibit non-entropic tendencies", which opposes the second law of thermodynamics.

To understand processes in the condition of the introduction of emergent technologies, the main difference between open systems and closed (isolated) systems is important: according to Bertalanffy, an open system reaches a state of mobile equilibrium, in which its structure remains constant. But unlike ordinary equilibrium state, this constancy is maintained in the process of continuous exchange and movement of matter $[5, \mathrm{p} .42]$.

In parallel with the research of L. von Bertalanffy, in the period of the 1930s, the Soviet scientist E. Bauer investigated one of the features important for understanding the process of the development of living systems - the fundamental disequilibrium of living systems, i.e., the desire to maintain stable nonequilibrium and use energy to maintain oneself in a disequilibrium state. E. Bauer explains this by saying that the structures of living cells at the molecular level are pre-charged with "excess" energy that is excessive in comparison with the same inanimate molecule, and the body does use energy from outside not for work, but to maintaintion a nonequilibrium structure [6].

Thanks to the law of L. von Bertalanffy and the principle of E. Bauer, the system shows: the ability to withstand entropy (destroying the system) trends, to show the ability to adapt to changing environmental conditions and interference, both to external and internal, the ability to develop options behavior and change, if necessary, self structure, while maintaining integrity; ability and desire for purpose-setting.

These features have a variety of manifestations. On the one hand, these include properties useful for the existence of the system, its adaptability to changing environmental conditions, but at the same time, these features cause: irreducible indeterminacy, non-stationary parameters, instability of the system, unpredictable behavior.

Studies have shown that, thus, the development of an open system occurs: 1) due to the exchange of information, energy, material components (i.e. the openness of the system) with the environment and 2) due to the active elements that initiate own innovations and ensure the interaction of innovations.

Features of open systems are due to the presence of active elements that stimulate the exchange of material, energy and information products with the environment and display their own "initiatives", an active principle. Owing to this, in such systems the regularity of increasing entropy is violated and negentropic tendencies are observed, i.e., self-organization itself, development.

The role of active elements in an open system is countertalkative. Thanks to the active elements of the open system, which initiate innovations and their interaction, a new quality arises, i.e., a regularity of emergence appears, which is the main non-entropic tendencies that counteract the law of in- 
creasing entropy in closed systems (i.e., the second law of thermodynamics ), which ensures the development of open systems according to L. von Bertalanffy. At the same time, due to initiatives of active elements and innovations, problems of maintaining stability, the ability to withstand unwanted results that may arise from the joint implementation of heterogeneous innovations arise. Research conducted in the theory of innovation has shown that any innovation disrupts the normal functioning of enterprises and organizations, creates a situation of "creative destruction" according to J. Schumpeter [7]. And the entropy, which were considered a manifestation of disorder, on the contrary, stabilize the state of the system, since the minimum energy state to which the entropy processes lead is the most stable.

The regularities of the theory of systems help to understand these contradictions, to evaluate the degree of manifestation of entropy and non-entropy tendencies.

It is necessary to develop management models for the sustainable development of enterprises and organizations in the condition of introducing and using innovations, especially fundamentally new emerging technologies.

When managing the development of open systems, the problem arises of a comparative analysis and selection of innovative technologies, taking into account their features, capabilities, usefulness and consequences of their implementation. This is beginning to be realized and models are being developed for choosing and managing the introduction of innovations (for example, [8-10]), training personnel for working in the new information environment [11].

In developing these models, methods and models of system theory are used. In particular, it is proposed to apply 3 methods for organizing complex examinations based on the information theory of A.A. Denisov [12]:

1) a method for assessing the significance of $H_{i}$ innovation, based on the assessment of the degree of purpose-compliance:

$$
H_{i}=-q_{i} \log \left(1-p_{i}^{\prime}\right),
$$

where $p_{i}$ '- the probability of achieving the goal when using the technology, and $q_{i}$ - the probability that the evaluated technology will be implemented and / or used;

2) a method of comparative analysis of the evaluated components during the initial period of their implementation by comparing the changes of the information estimates over time, based on the use of two methods of assessment - probabilistic method (1) and deterministic method:

$$
H=\sqrt[\gamma]{\frac{1}{n} \sum_{i=1}^{n} J_{i}^{\gamma}},
$$

where $J_{i}$ - information about the innovation, $n$ - volume concept about measurement-covering innovation parameters;

$\gamma$-averaging parameter. When $\gamma=1$, that means $H_{i}=J_{i} / n_{i}$.

3) a method for assessing situations, taking into account the mutual influence of the evaluated components, described by information equations in statics and dynamics:

$$
H_{i}=H_{i i}+H_{i j}
$$

where $H_{i i}$, - the own importance of technologies in the absence of other technologies affecting its value; $H_{i j}$,- change in the relevance; of the $i$-th technology in the presence of the $j$-th.

To manage the development of artificially created, and in particular, cyberphysical systems, it is important to rethink the essence, the state of the prospects for the development of the concept of open systems. Therefore, acquaintance with interdisciplinary knowledge, and in particular with the theory of systems, is useful for almost all specialties.

\section{ANALYSIS OF NEW FORMS OF EDUCATIONAL PROCESS ORGANIZATION}

Problems of education are discussed at the International Forum of Innovative Development "Open Innovations", regularly held since October 31, 2012, which is considered to be a global discussion platform dedicated to the latest technologies.

In development of the form of distance education, it is planned to create a common online platform that will allow the use of artificial intelligence technologies in training, and create a system that provides students with access to a second (digital) profession, i.e. specialty, which will be in demand in the conditions of introduction of innovative technologies.

Such tasks were set on July 11, 2019 at the 7th International Forum "Open Innovations", in "Skoltech", where the first day of the program was devoted to education. Russian entrepreneurs, scientists and managers discussed the problems of modernizing the Russian education system to increase its competitiveness.

In the process of preparing and holding the forum, the correspondent of the "Snob" journal Arina Kryuchkova talked with its participants and learned four rules for the formation of the future [https://snob.ru/entry/179824/], which, in our opinion, are controversial:

1. Education will become a regular service, and its result will be guaranteed.

At the same time, it is proposed to conduct individual tests, select teachers that are suitable according to the psychological characteristics, and group students according to their personal goals.

Comments. The task of striving for individualization of training has always been posed, and teachers, as possible, try to solve it with the help of individualization of tasks on term papers. However, for the time being, the current load standards of university teachers do not help. It is advisable for the Ministry of Science and Higher Education to try to develop necessary regulatory and methodological materials. This will improve the quality of education, but in any case, education cannot be considered a "regular service", and the result is guaranteed.

\section{Education will almost completely go online.}

The General Director of the the University 20.35 Vasily Tretyakov is sure of this. According to him, in the future, the student will view lectures in the recording, learn using games 
in virtual reality and take testing on the network. Further recommended systems will work with this information: they will either offer a graduate a suitable field of activity, or build a further development trajectory. This will allow people to more effectively reveal their own potential.

\section{Schools and universities will disappear.}

The fact that students will begin to gain knowledge bypassing educational institutions is sure of the scientific director of the Institute of Education at the Higher School of Economics Isak Frumin. In the near future, pupils and students will not need to appear in the educational institution, they will be able to receive all the information directly from the teacher at home. For example, according to I. Frumin, many studies show that lectures are the most inefficient format of instruction. So, at the Higher School of Economics, a decision has already been made to switch to video lectures and offer students independent study and work in groups, while retaining the best lecturers.

As for home education, I. Frumin emphasizes that learning involves interaction, and therefore this form of training can be uncomfortable. However, the rapidly developing means of communication are successfully solving this problem.

Comments. Of course, the planned creation of a single online platform will allow dozens of Russian universities to use artificial intelligence technologies in training, to receive information about new technologies, or even get a second profession (digital profession).

At the same time, the main problem is the established patterns of education: if older people cannot refuse libraries and physical media (paper textbooks), then it is premature to talk about abandoning schools and universities. It is necessary to gradually look for new forms of organization of the educational process.

Universities and schools solve not only the problem of knowledge transfer, but also the problems of education and personality formation, which becomes even more relevant in the context of introducing unpredictable "fantastic" technologies. The transformation of universities and schools is inevitable, but extinction is unpromising.

\section{Pupils themselves will manage their education.}

Comments. Students have the right to manage their education. They can offer their own topics for course works and degree works, choose a form of education process on the basis of individual plans. At the same time, it is known that there are few such willing, creative-minded students. Most are conformists, preferring to work by analogy or borrow information from previous works. The scientific-research system for students in universities helps to shape the desire to manage their education; in schools there are extracurricular activities such as scientific clubs and technical sections.

\section{CONCLUSION}

The analysis of the influence of emergent technologies on personnel training and educational system allows us to con- clude that the main influence is exerted by the integrated use of technologies to obtain fundamentally new results. Therefore, taking into account the fact that new, often seemingly fantastic, opportunities obtained as a result of combining technologies are still not well understood. This statement also applies to understanding the consequences of the creation and widespread adoption of such technologies, and it is advisable to account the regularities of system theory to explain the appearance of emergent properties of a system, a number of new disciplines are needed in which the types and features of technologies are studied, as well as methods of systems theory, artificial intelligence, engineering, models of analysis for and the choice of technologies. It is also necessary to search for new forms of organization of the educational process.

\section{REFERENCES}

[1] Volkova V.N. Emerdzhentnost', sinergiya ili konvergentsiya? [Emergentness, synergy or convergence?] Sistemnyy analiz v proyekte $i$ upravlenii: sbornik nauchnykh trudov XXI Mezhdunarodnoy nauchnoprakticheskoy konferentsii. St. Petersburg, 2016. P. 149-160. (In Russian)

[2] Marsh P. Novaya promyshlennaya revolyutsiya. Potrebiteli, globalizatsiya $i$ konets massovogo proizvodstva [The New Industrial Revolution: Consumers, Globalization and the End of Mass Production]. Moscow, Institut Gaidara Publ., 2015. 420 p. (In Russian)

[3] Anderson Chris. Markers: The New Industrial Revolution. New York, NY: Crown Publishing Group, 2012. 272 p.

[4] Shvab K. Chetvertaya promyshlennaya revolyutsiya. [The Fourth Indusyrial Revolution]. Moscow, "E” Publ. 2017. 208 p. (In Russian).

[5] Bertalanfi L. fon. Teoriya sistem: kriticheskii obzor [General theory of systems: critical review]. Investigations on the general theory of systems. Moscow: Progress Publ., 1969. P. 23-82. (In Russian).

[6] Bauer E.S. Teoreticheskaya biologiya. [Theoretical Biology] Moscow, Leningrad: VIEM Publ., 1935. 206 p. (In Russian).

[7] Schumpeter J. Teoriya ekonomicheskogo razvitiya [The theory of economic development]. Moscow: Progress Publ., 1982. (In Russian).

[8] V.N. Volkova, A.V. Loginova, A.Ye. Leonova, Yu.Yu. Chernyy. Approach to comparative analysis and selection of technological innovations of the third and fourth industrial revolutions. Proc. of the 21st International Conference on Soft Computing and Measurement (SCM-2018), St. Petersburg, 23-25 may 2018, Saint Petersburg Electrotechnical University “LETI” Publ. P. 373-376.

[9] Volkova V.N., Kudryavtseva A.S. Models for managing the innovation activities of industrial enterprises, Otkrytoye obrazovaniye [Open Education J.], 22(4), 64-73, (2018), (In Russian).

[10] Kudryavtseva A.S. Models for the management of industrial enterprises in the implementation of technological innovations, Proc. of 22th Intern. scientific practical conf. System analysis in engineering and control, Part 1, St. Petersburg Polytechnic University Publishing House, 389-398, (2018), (In Russian).

[11] Volkova V.N., Kozlov V.N., Karlik A.E. and Iakovleva E.A. The impact of NBIC-technology development on engineering and management personnel training, Strategic Partnership of Universities and Enterprises of Hi-Tech Branches. (Science, Education, Innovation), 6, 51-54, (2018).

[12] Denisov A.A. Sovremennye problemy sistemnogo analiza: uchebnik [Modern problems of system analysis: a textbook]. SPb.: 3-e izd. Politekhn. un-ta Publ. 2008. 304 p. (In Russian)

[13] Emerging Technologies | HuffPost/huffingtonpost.com»topic/ emergingtechnologies. 